\title{
Profitability, Audit Quality, and Firm Value: Case on Indonesian \\ Manufacturing Companies
}

\section{Anggita Langgeng Wijaya}

Department of Accounting

Universitas PGRI Madiun

This study will examine the effect of profitability on firm value with audit quality as a moderating variable. This research was conducted at the manufacturing firm listed on the Indonesian capital market in 2013-2017. The population in this study are all manufacturing firm listed on the Indonesian capital market. The research sample was obtained by using the purposive method. The research data were analyzed moderated regression analysis. The results of this study indicate that; 1) profitability has a positive effect on the value of manufacturing firms on the Indonesian capital market, 2). Audit quality strengthens the effect of profitability on the value of a manufacturing firm on the Indonesian capital market. This research proves that there is a positive response from investors in the Indonesian capital market on reporting earnings from companies audited by the big four public accounting firms.

Keywords: Earnings, Profitability, Audit Quality, Big 4, Firm Value

\section{Rentabilidad, calidad de la auditoría y valor de la empresa: caso de empresas manufactureras de Indonesia}

Este estudio examinará el efecto de la rentabilidad en el valor de la empresa tomando la calidad de la auditoría como variable moderada. Esta investigación se llevó a cabo en la empresa de fabricación que cotiza en el mercado de capitales de Indonesia en el periodo 2013-2017. La población de este estudio está compuesta por todas las empresas manufactureras que cotizan en el mercado de capitales de Indonesia. La muestra de investigación se obtuvo mediante el método previsto. Se analizaron los datos de búsqueda y la regresión promediada. Los resultados de este estudio indican que 1) la rentabilidad tiene un efecto positivo sobre el valor de las empresas industriales en el mercado de capitales de Indonesia; y 2) la calidad de auditoría refuerza el impacto de la rentabilidad sobre el valor del fabricante en el mercado de capitales de Indonesia. Esta investigación demuestra que hay una respuesta positiva de los inversores en el mercado de capitales de Indonesia cuando informan las ganancias corporativas auditadas por las firmas Big Four CPA.

Palabras clave: Ganancias, rentabilidad, calidad de auditoría, Big 4, valor firme

\section{Rentabilidade, auditoria da qualidade e valor da empresa: caso em empresas de manufatura indonésias}

Este estudo examinará o efeito da lucratividade no valor da empresa com a qualidade da auditoria como uma variável moderadora. Esta pesquisa foi realizada na empresa de manufatura listada no mercado de capitais da Indonésia em 2013-2017. A população deste estudo são todas as empresas de manufatura listadas no mercado de capitais da Indonésia. A amostra da pesquisa foi obtida pelo método objetivo. Os dados da pesquisa foram analisados análise de regressão moderada. Os resultados deste estudo indicam que; 1) a lucratividade tem um efeito positivo no valor das empresas de 
manufatura no mercado de capitais da Indonésia, 2). A auditoria da qualidade fortalece o efeito da lucratividade no valor de uma empresa de manufatura no mercado de capitais da Indonésia. Esta pesquisa prova que há uma resposta positiva dos investidores no mercado de capitais da Indonésia em relatar ganhos de empresas auditadas pelas quatro grandes empresas de contabilidade pública.

Palavras-chave: Lucro, Rentabilidade, Qualidade da Auditoria, Big 4, Valor da Empresa

\section{Introduction}

AlNajjar and Belkaoui (1999) explain that financial reporting is an instrument that provides information about the company's business activities. Information in financial reporting is used by users of financial statements for various business purposes. One of the information in financial statements that gets more attention from users of financial statements is earnings value. Earnings figures are generated from the company's income statement mechanism. Kieso et al. (2011) state that one of the income statement's weaknesses is the reported earnings figures obtained from the selection of accounting methods that may differ between companies and have an element of judgment in their reporting.

Kazemi et al. (2011) explained that profit is an indicator of management performance evaluation and is also a determinant of the company's economic value. In explaining agency relationships, information on earnings has the potential to be an information asymmetry problem due to the quality of information on earnings reported by the company. Company managers are responsible for applying estimates and applying necessary judgments in the selection of accounting methods. On the other hand, company managers are concerned with reporting the earnings figures. In this situation, the potential for a conflict of interest is very significant. Meanwhile, according to Barth and Landsman (2018), profit figures determine the firm value in the capital market.
Reyad (2013) states that financial statements aim to produce information that can be used by interested parties to assess the performance of company managers and make business decisions. AlNajjar and Belkaoui (1999) explain that the figures presented in financial statements are also used by the market to assess companies. Users of financial statements assume that the information received is reliable and fit for business decision making. Accounting standards become guidelines for preparing financial reporting so that investors and potential investors get information in a balanced portion.

LaFond and Watts (2008) explain that investors and potential investors need information in the capital market. The information needed is not limited to past performance and information on the value of the company's net assets but also about its future performance. In this case, investors' ability will be limited by the credibility of the information provided by company managers. If the information is not verified correctly, it becomes easy to manipulate company managers and becomes information not credible for investors. This situation will increase information asymmetry, which will affect investors' difficulties in evaluating companies.

AlNajjar and Belkaoui (1999) state that profitability is the company's financial ratio that shows its ability to generate profits compared to certain factors such as the number of assets, the number of sales, or the amount of capital the company. According to Liow 
(2010), profitability is the primary performance indicator that influences firm value. Investors are willing to pay more for profitable companies with several assumptions, including positive aspects of corporate leverage, high and sustainable company growth, and prospects for long-term profitability. Investors can optimize their finances by forming portfolios of companies with good profitability. However, the direction of profit or loss will be significantly influenced by each capital market's character.

This study will examine the relationship between company profitability and firm value by considering audit quality as a moderating variable. Fairfield et al. (2003) explain that profitability is a market concern in determining its value. Dennis et al. (2019) explain that company management has the primary responsibility to provide original information about its condition through management assertions in the financial reporting system. The information presented in the financial statements will be used by users for various aspects, such as investment decisions and providing company value. Jensen and Meckling (1976) explain that principals can create a supervisory mechanism for agents in an agency relationship. One of them is by implementing good governance and supervision through an audit process by an independent external party. Company management is expected not to abuse their authority and work properly in the company's owners' interests with the implementation of good corporate governance and rigorous external audits. Quality auditors are expected to reduce errors in presenting financial statements, prevent structured financial fraud, reduce excess accruals on earnings management, and improve the quality of the company's financial statements (Dennis et al., 2019).

Hamdan et al. (2012) state that audit quality became an essential issue when various global corporate financial scandals involved accountants and auditors. A quality audit process should detect unusual transactions in the financial statements, prevent material errors, and communicate the findings with management before issuing the audit report. Based on the explanation of Balsam et al. (2003), an external audit is a process of evaluating an independent party on the reasonableness of the information presented in the financial statements. External auditors assure that the financial statements have been prepared by accounting standards and have presented accurately and reliably about the company's financial position and performance. Information on audited financial statements will impact stock prices in the market, so audit quality must always be maintained and improved.

In Indonesian's context, the Indonesian capital market is the capital market with an emerging market type. According to Purwohandoko (2017), information on earnings becomes information that influences the fluctuation of equity prices in the capital market. Kontesa (2015) adds that in the Indonesian capital market, profitability is a crucial indicator of company performance. The higher the company's performance, the more investors will want to buy the company's shares, this will cause an increase in the company's stock price. Excellent company performance will have an impact on increasing firm value.

Skinner and Srinivasan (2012) state that mistakes in providing firm value are wrong business decisions and are risky for investors. Kieso et al. (2011) explain that financial statements are prepared on an accrual basis, so the potential for judgment on the accrual basis of financial reporting is high and affects the numbers in financial reporting. Balsam et al. (2003) mentioned that the financial statements prepared on the accrual basis cause prone to earnings management actions. Earnings management actions will cause financial 
statements that do not reflect real business conditions. Audit quality has a role in efforts to suppress the occurrence of earnings management and pressure management to use more conservative financial statements. Wang and Huang (2014) state that users of financial statements in the capital market will be facilitated if the auditor can produce an audited financial report appropriately according to accounting standards, free of bias and free of material errors. The situation is expected to improve the accuracy of business decisions of investors and potential investors in the capital market.

The researcher believes that if profitability is essential for investors to assess performance and provide firm value, audit quality is expected to give investors more confidence to provide more appropriate values. Investor response to company earnings information will be more durable with the support of more accurate and credible financial statement information as a result of quality audits. Investors are expected to give a higher firm value to companies that have excellent financial performance and, at the same time, be audited by higher quality auditors. Thus, audit quality is a factor that is predicted to strengthen the effect of profitability on the firm value on the Indonesian capital market.

\section{Literature Review and Development of Hypotheses}

\subsection{Earnings and Firm Value}

According to Sucuahi and Cambarihan (2016), every business organization's primary goal is to maximize firm value. Maximizing the company's value is essential for the company because it means increasing its shareholders' welfare. One of the factors that influence the company's value is the company's ability to generate earnings. The higher the company's ability to generate earnings, the more significant the potential increase in corporate assets, which means the higher the value and the welfare of shareholders. Dang et al. (2019) explain that efforts to maximize firm value must be a continuous business process. Accounting earnings are accrual numbers that are not necessarily the same as the cash flows generated by the company. Efforts to increase the value of assets must be balanced with efforts to increase the company's stock price in the capital market.

According to Dimitropoulos and Asteriou (2009), the relationship between earnings and returns has been studied more than thirty years ago since Ball and Brown (1968) researched this topic. Earnings figures will be used by investors and analysts to predict future cash flows and the calculation of investment risk. The company's earnings analysis results are also the basis for investors in providing value for the company's shares. Ohlson and Shroff (1992) explain that corporate profits impact changes in company stock returns. Earnings currently play the role of investor expectations of corporate profits, and changes in profits can have both positive and negative effects on returns. Naturally, the increase in profits becomes useful information that can increase stock prices and vice versa.

Mule et al. (2015) explain that profitability and market value are critical for company management's efficiency and performance. The company's efficiency can be seen from the company's ability to reduce various costs so that the company's profitability can increase. Profitability is the company's ability to make money with available resources, while the company's value is the market capitalization of the book value of the company's assets. Mule et al. (2015) explain that company size is one of the factors that influences company value. The company's size guarantees competitive 
advantages such as promising business prospects, proper business management, high bargaining power of investment, and the company's ability to pay off debt and lower business risk.

Pfeiffera and Shields (2015) explain that there are two ways to limit corporate management's moral hazard from the perspective of agency theory (Jensen \& Meckling, 1976). First, increase executive efforts to limit moral hazard through compensation contracts. Compensation contracts provide financial incentives for management to increase their business on behalf of the company. Compensation contracts are also useful for owners to sort contracts and the manager's capabilities. The second is the disclosure of private information by the executive. If the compensation contract goes well, the manager chooses to release private information and chooses to work to get the maximum payment and try his best to reduce company costs. Appropriate compensation contracts will get a market response with increasing firm value.

Barth and Landsman (2018) explained that in the 1980 s, researchers had stated that profit was a predictive value for measuring firm value. The ratio of earnings to stock prices is considered to have a more appropriate measure of company value than the book value of equity. Easton and Harris (1991) introduce a prospective valuation of company shares. This study explains that firm value is a function of accounting earnings while return (price changes) is a function of changes in book value and changes in accounting earnings. Ball et al. (1993) explain that in the standard valuation model, earnings have an impact on expected returns on equity. Changes in corporate profits will impact on changes in company stock prices so that it has an impact on return. The sensitivity of the change between earnings and returns can be interpreted as an investor's assessment of the company's investment risk.

\subsection{Audit Quality}

Lin and Hwang (2010) explain that external auditing is an effort from the principal to control agent behavior in the agency relationship. The auditor will verify the financial statements prepared by management as an independent party. The audit process is carried out with the aim that financial reporting has been prepared according to accounting standards, does not contain material errors, and shows the company's actual business activities. Audit quality is a very important aspect for those directly or indirectly related to the substance of the company's financial statements. With an external quality audit, it is expected that the credibility and quality of financial statements will increase, earnings management actions can be reduced and minimize the risk of misstatement in financial reporting.

Reyad (2013) explains that audit quality is expected to improve information quality by reducing miss statements and structured fraud in the presentation of financial statements. Fooladi and Farhadi (2011) explain that the external audit process assures external users that the financial statements have presented all material things accurately and objectively in the company's business activities. Audit quality is part of the corporate governance mechanism designed to protect the rights of corporate shareholders. In the perspective of agency theory, audit quality is a structured mechanism to reduce information asymmetry and reduce the adverse effects of agency conflict.

This research was developed based on DeAngelo (1981), which uses big four and non-big four public accounting firms (the research is still big 8 ) to measure audit quality. DeAngelo (1981) defines audit quality as the probability of the auditor's ability to find and report material misstatements in financial statements. There are several explanations for why big four 
auditors are considered to have better audit quality. Big four public accountants are considered to have greater independence, capability, and experience than non-big four. Big four public accounting firms have substantial financial capital so that it has an impact on better ability in human resource investment, staff training, and technology use. The audit work process will run according to the ideal corridor and will not be affected by the client's audit fees. Legal exposure and reputation risk are of great concern as efforts to protect the public interest as users of financial statements.

Francis and Wang (2008) explain that the big four auditors have an international audit market share and have a global affiliate office and clients from various countries. Because the audit scope is global, big four auditors face the complexity of assignments and business risks that are not the same in each audit check. The occurrence of accounting scandals on global companies has made various parties aware of the importance of audit quality. Big four public accounting firms must strive to consistently treat their clients by implementing quality audits and applying the principles of accounting conservatism. Balsam et al. (2003) explain that the importance of contracts and management compensation is an incentive for managers to manage corporate earnings reporting. This profit management has the potential to harm the principal's interests as the owner of the company. A quality audit process becomes a critical component used to limit the opportunistic behavior of management in reporting earnings. The big four auditors have the advantage of experience, competence, and reputation in providing guarantees for a higher quality audit process.

Jiang et al. (2019) stated that the study of Big N auditors and Non-Big $\mathrm{N}$ auditors regarding audit quality has been and is still a research debate in the audit field. Audit quality that is owned by the big $\mathrm{N}$ auditor is influenced by an explanation of office size, reputation and independence factors, competence and excellence of human resources and excellence in the field of information technology. Hurley and Mayhew (2019) explain that theoretically, company managers will ask for a quality audit process to prevent price protection behavior from investors. The high demand for a quality audit process will lead to competition among auditors to meet the audit quality demanded by the market. Chen et al. (2020) explain that one of the indicators of the quality of financial reports is the increasing of the comparability of the company's earnings reports. Audit quality affects the company's earning comparability level. This study finds that the individual auditor's style affects the audit reporting style of the public accounting firm and affects the way the company's financial statements are presented. Chen et al. (2020) found that senior auditors and more constant work team will make the audit process more consistent and accurate in applying GAAP during the audit engagement.

\subsection{Hypothesis Development}

\subsubsection{Profitability and Firm Value}

Mian and Sankaraguruswamy (2012) explain that accounting research has long been interested in evaluating and the implications of corporate earnings figures. In the concept of an efficient market, accounting information will be reflected in the company's stock price, which explains the role of agents and the capital market. Beaver (1968) explains that the profit rate contains information that is reacted by the capital market. Changes in prices and changes in stock trading volume indicate a market reaction to the information presented in financial reporting. Ofer (1975) explains that information on earnings affects the company's stock price due to two ways of looking. The first point of view, profit shows the risk companies that investors 
bear for the company's business. The second perspective explains that profit growth shows the prospect of the company's profit in the future.

According to agency theory, corporate earnings are the primary information that has implications for many aspects of the relationship between principals and agents (Jensen \& Meckling, 1976). Achievement of profits is the basis for the formulation of compensation contracts for company managers (LaFond \& Watts, 2008). Profit figures become the basis for users of financial statements to provide more precise value on company performance (Chan et al., 2005). Information about profits becomes a signal that the right agent-oriented manages the company towards the principal's interests. The company's ability to generate profits is also the basis for assessing and forecasting its business prospects (Chen et al., 2014).

Kazemi et al. (2011) explain that users of financial statements expect the company's reported earnings figures to reflect real profit. Investors believe that when a company reports real profit, the profit will come from the regular transaction of the company's business, which will be repeated and will be reflected in earnings in the following year and is directly proportional to the realization of cash flow. Kerr and Ozel (2015) explain that information on corporate profits is sensitive information for the capital market. This company's profit growth is a good indicator of its profitability and business prospects in the future. Shareholders and potential investors need precise information on the company's performance to provide value to the company. The value given by investors and potential investors shows the expectation of return obtained in the future.

Lev (1989) states that one of the potential benefits of corporate earnings information is to limit the occurrence of information asymmetry in the capital market.

The information value of company profits will be reflected in economic events that affect the company's stock price. Information on earnings helps investors to predict future cash flows to be received. Senteney (1991) explains that there is a market reaction when company earnings announcements occur where the market reacts more when company profits are positive than negative earnings when compared to the previous period. Brooks (1994) explains that there are significant changes in the market when announcements occur about company profits. This condition shows that earnings announcements contain aspects of information that can affect the company's volume and price.

Chen and Chen (2011) explain that in the era of a highly competitive business environment, efficient businesses need to be taken by management in order to improve welfare and firm value. Companies with high profitability have the prospect of higher profit distribution to shareholders so that the company's value is expected to increase. Saji and Harikumar (2015) conducted a study on the relationship between earnings growth and stock price changes in Indian companies. The results of this study indicate that investors in forming a portfolio tend to buy shares of companies that have the highest profit growth. The results of this study indicate that earnings growth information is positive for investors. Companies with profit growth are considered to provide guarantees for investment security and good business prospects for investors.

Ghosh et al. (2005) conducted a study between earnings growth, revenue growth, earnings quality, and earnings response coefficient (ERC). According to this study, the earnings response coefficient (ERC) is a measure of earnings relationship with the company's stock price. The higher the value of the ERC indicates the higher the relevance of information about earnings information. Ghosh et al. (2005) state that 
the earnings of companies experiencing growth have a high value of changes in the earnings response coefficient. Companies that have sustained earnings growth and are followed by high revenue growth have a high earnings response coefficient.

Tamrin et al. (2017) stated that the synergy between investment, financial and dividend policy is the main factor determining firm value. Corporate governance structure and company financial policies are mechanisms created to increase the company's profitability. Profitability shows the company's ability to generate earnings compared to sales, assets and company capital. Long-term investors focus on profitability analysis to obtain increased welfare in the form of dividends, future cash flows and an increase in company investment. Research by Tamrin et al. (2017) found a direct effect of profitability on the value of manufacturing companies on the Indonesia Stock Exchange. However, it failed to find the role of corporate governance and dividends as mediating variables between profitability and firm value.

According to Purwohandoko (2017), the higher the company's performance will affect the higher stock prices. Company performance can be seen from the company's ability to generate profits. The increase in share prices in the capital market shows an increase in the value of the company. Mian and Sankaraguruswamy (2012) explained that the capital market has a sensitivity to the announcement of company profits. The capital market gives a positive reaction to earnings information that is good news and gives an adverse reaction when earnings information is bad news. This situation provides an over-evaluation of the company's performance because the profit figures are prepared on the accrual basis, which management has judgment in reporting. Improper evaluation results in overpricing or underpricing of the company's stock price.
Orpurt and Zhang (2009) explain that the primary purpose of financial reporting is to provide information that helps users of financial statements assess the amount and timing of company cash flows and profits. A company's ability to generate cash flow and profits is related to firm value in the market. Kontesa (2015) states that company profitability explains how well company managers manage their resources. The company's ability to generate profits will attract investors to invest in the company. Investment decisions are carried out to get sustainable profits in the future. The increase in corporate earnings is expected to be in line with the movement of the company's stock prices in the market so that it has an impact on increasing returns for investors. The higher the increase in corporate profits, the higher the potential increase in the welfare of the company's shareholders. Based on the explanation above, the hypothesis in this study is stated as follows.

$\mathrm{H}_{1}$ : Profitability has a positive effect on firm value of manufacturing firm on the Indonesian capital market.

\subsubsection{The Moderation Role of Audit Quality}

Afza and Nazir (2014) stated that a steady and sustainable increase in earnings is the hope of many investors. The increase in company earnings is expected to be directly proportional to the cash flow distribution to the owner, which means investors will get a positive return on their investment in the company. This condition is expected to increase welfare and also firm value. The data presented in the financial statements are the basis for investors in observing the company's business development. Firm value shows investors and potential investors' perspectives and expectations for the company's performance and business prospects. Kronenberger and Pietzsch (2017) state that company managers prepare financial statements as a form of 
responsibility for managing the company's business to the owner, while the external audit functions as a verifier of financial statements prepared by management. Alsmairat et al. (2018) submit that an external audit is a mechanism created to reduce agency costs, limit the manager's opportunistic behavior, and to reduce the risks faced by company owners.

Reyad (2012) explains that the study of audit quality is always associated with the quality of financial statements. Doyle et al. (2007) state that the quality of the information in financial statements can be low because of two explanations. The first explanation is that management intentionally reports biased accruals caused by earnings management. The second explanation is accidental errors in accrual valuation caused by difficulties in recording, difficulties in predicting future events, or because of weak controls that cause errors in reporting data. The role of moderation of audit quality in the relationship between company profitability and firm value in this study is seen from the benefits and competitive advantages of audit quality, especially audit conducted by big 4 public accountants. Francis and Yu (2009) state that the audited financial statements by higher quality auditors rarely contain material misstatements. The Big 4 auditor has the ability and experience that causes the auditor to be better able to detect material misstatements and ask clients to make corrections before the audit report is issued. Audit quality will minimize agency costs due to the positive impact of higher quality financial statements.

Li and Lin (2005) explain that managers have specific motivations for managing earnings. Beyer et al. (2019) state that managers' financial statements will affect the company's stock price. If the company manager does not report actual earnings, there will be a miss-report on earnings reporting. This reporting error will impact the occurrence of bias in earnings reporting for the following year. Bias for earnings reporting will impact increased costs, higher asymmetry of information, and weak financial statements. Audit quality plays a role in reducing earnings management and improving the quality of financial statements (Verdi, 2006). Balsam et al. (2003) states that auditor size is positively associated with a quality audit process. Balsam's research (2003) found that companies audited by big six auditors had a smaller discretionary accrual, higher associations between stock returns and discretionary accruals, and higher-earning associations with future profitability if compared to auditors from non-big 6 .

Aobdia et al. (2015) state that audit quality is a mechanism created to improve data quality in financial reporting. One indicator of information quality is the high relevance of investment decisions in the capital market. Audit quality has a positive impact on the capital market. Audit quality gives investors a positive signal over the quality of financial statement information that is the basis for valuing companies. Audit quality becomes an important component to reduce the level of information asymmetry in the capital market. Alsmairat et al. (2018) argue that high audit quality can prevent material misstatement, prevent fraud, minimize audit risk, and reduce corporate earnings management. High audit quality is a form of anticipating litigation risk from potentially disadvantaged parties on financial statement information. The stock market gives a positive reaction to companies that use public accountants' services with high audit quality.

Elliott et al. (2020) state that the firm value estimate influences investors' willingness to buy company shares. Investors may have different interpretations of the information available in the financial statements, but the quality of the financial statements has been theorized to be a factor affecting firm value. According to Elliott et al. (2020), the effect of the quality of financial 
statements on firm value will be strengthened by the quality of the audit process. The quality audit can be seen through the existence of an effective communication mechanism between auditors and company management through auditor comments written in independent audit reports. The auditor's comments are believed to be an indicator of the quality of the financial statements that will make investors willing to pay for the company's shares at the highest price compared to companies with low-quality financial statements.

Eshleman and Guo (2014) stated that the lack of a process of restatement of corporate earnings reports is an explanation of why big-4 auditors have higher audit quality when compared to non-big 4 . Hussainey (2009) found that audit quality is directly proportional to the accuracy of earnings predictability. Investors' ability to predict and anticipate future earnings will increase if the company's financial statements are audited by one of the big four auditors. Hussainey's research (2009) does not apply to unprofitable firms, which means that the ability to predict earnings will increase in companies that profit and, at the same time, are audited by the big- 4 auditors.

Researchers argue that if profitability is essential information that can increase firm value (Mian \& Sankaraguruswamy, 2012; Purwohandoko, 2017), audit quality will improve the accuracy of information presented in financial statements. Quality audits provide benefits for users of financial statements, such as reducing earnings management (Balsam et al., 2003), increasing ERC and earnings persistence (Balsam et al., 2003), minimizing the occurrence of restatement (Eshleman \& Guo., 2014), increasing accuracy and the quality of financial statements (Aobdia et al., 2015), increasing the ability to predict earnings (Hussainey, 2009), reducing agency costs and information asymmetry (Francis \& Yu, 2009). Capital market reaction to company profitability will be more reliable if, at the same time, the company is audited by auditor big four. Audit quality will strengthen the positive response to company earnings information. Audit quality further increases the confidence of users of financial statements on company earnings information. Audit quality is thought to be a moderating variable that strengthens the effect of profitability on firm value in Indonesian's stock exchange.

Based on the explanation above, the hypothesis in this study is stated as follows.

$\mathrm{H}_{2}$ : Audit quality strengthens the effect of profitability on the firm value of manufacturing firm on the Indonesian capital market.

\section{Methodology}

\subsection{Research Data}

This research was conducted at the Indonesian capital market (IDX) with a research period of 2013 to 2017. The population of this study was all manufacturing industry companies in the Indonesian capital market. This research data was obtained from audited financial statements, annual reports, and company performance summary documents on the Indonesian capital market. Researchers used a purposive sampling method in the sample selection technique of this study. The research sampling criteria are set as follows:

- This company is a manufacturing industry company on IDX (Indonesian capital market) from 2013 to 2017.

- The company has audited financial statements.

- The company does not experience a shortage of capital and has complete financial data with researchers' data analysis needs. 


\subsection{Definition of Operational Variables}

\subsubsection{Independent Variable}

Company profitability is an independent variable in this study. Mule et al. (2015) explain that profitability is a financial ratio that shows a company's ability to generate earnings. The higher the profitability ratio indicates, the better the company's performance. The company's profitability in this study is proxied by return on assets (ROA). Return on assets (ROA) is a financial ratio that compares the company's net income with its total assets (Mule et al., 2015).

\subsubsection{Moderation Variable}

Audit quality has a function as a moderating variable in this study. Based on DeAngelo (1981), audit quality is proxied by dummy variables for big- 4 and nonbig- 4 auditors. If a big- 4 public accountant audits the company's financial statements, they are statistically given a value of 1 and given a value of 0 otherwise.

\subsubsection{Dependent Variable}

Firm value is the dependent variable in this study. Firm value shows investors' appreciation in the Indonesian capital market for its manager's performance manifested by changes in the company's stock price. Based on Wang and Huang (2014), the firm value in this study's analysis is proxied by the Tobin Q formula. Tobin $\mathrm{Q}$ measures firm value by comparing the equity market value plus total debt, divided by the company's total assets.

\subsubsection{Control Variable}

Firm size and debt ratio (leverage) have a function as a control variable in this study. Referring to Wang and Huang (2014), large companies are considered to have market power, easy access to markets, and smaller risks than smaller ones. The firm size in this study was measured by the natural log of total assets (Dang et al., 2019). Mule et al. (2015) explained that company size is one of the considerations of investors in determining firm value. The second control variable is leverage. Cano Rodríguez and Sánchez Alegría (2012) explain that the debt ratio is one of the investors' considerations in providing company value. High leverage carries the risk of bankruptcy, which can reduce firm value. If the company goes bankrupt, the primary recovery rights belong to the debt holders, while the shareholders bear the risk of residuals on the company's net assets. Regarding Wang and Huang (2014), leverage in this study is measured by the ratio of total debt divided by total company assets.

\subsection{Analysis Techniques}

Testing the hypothesis in this study was tested with two regression equation models. The first equation illustrates a multiple regression model, while the second equation describes a moderated regression analysis. The two regression equation models used in the analysis of this study are presented as follows.

TOBINQ $\mathrm{t}=\alpha+\beta 1$ ROA $\mathrm{t}+\beta 2$ DBIG4t $+\beta 3$ LNSI$\mathrm{ZE} \mathrm{t}+\beta 4$ LEVt e

TOBINQt $=\alpha+\beta 1$ ROA $t+\beta 2$ DBIG4t $+\beta 3$ ROA

* DBIG4t $+\beta 4$ LNSIZE $+\beta 5$ LEVt $+\mathrm{e}$

Information:

TOBINQt = Firm Value,

ROAt = profitability,

DBIG4t = audit quality,

LNSIZEt = firm size,

$\mathrm{LEVt}=$ leverage,

$\beta 1-\beta 5=$ regression coefficient (beta), and

e $\quad=$ error. 
The analysis of the regression model of this study included several tests, including the coefficient of determination (Adjusted R2), the F value of the regression and the $t$ value of the regression. This study makes a classical assumption that is a condition of a good regression model. The Classical assumption tests include data normality test, multicollinearity test, autocorrelation test, and heteroscedasticity test. Analysis of descriptive statistics and correlation matrix was also carried out to clarify the decryption of research data.

\section{Analysis and Discussion}

\subsection{Results of Data Collection}

The results of the selection of research data show that from 2013 to 2017, 137 manufacturing firm were listed sustainably on the Indonesian capital market. Based on checking the financial statement data's completeness, it is known that 95 manufacturing industry companies fulfill the financial reporting data completeness criteria. The number of observations over the five year study period was 475 company data. Based on the calculation of the debt ratio, 15 companies show capital deficiency conditions so that it is excluded from the analysis phase. The test results of the outlier data test showed that 60 company data showed the outlier data. The amount of outliner data was not included in the next analysis phase so that the number of observations used in this study was 400 company data.

\subsection{Descriptive Statistics}

In this section, the researcher will convey a description of the research data and the results of the correlation test between the research variables. The explanation of descriptive statistics includes an explanation of the minimum value, maximum value, average, and standard deviation. The number of samples for each variable is 400 , with a complete explanation of the data distribution presented in the following table.

Table 1. Descriptive statistics

\begin{tabular}{|c|c|c|c|c|c|}
\hline Variable & N & $\begin{array}{c}\text { Mini- } \\
\text { mum }\end{array}$ & $\begin{array}{c}\text { Maxi- } \\
\text { mum }\end{array}$ & Mean & $\begin{array}{c}\text { Standard } \\
\text { Deviation }\end{array}$ \\
\hline ROA & 400 & $-0,28$ & 0,36 & 0,04 & 0,08 \\
\hline DUMBIG4 & 400 & 0,00 & 1,00 & 0,32 & 0,47 \\
\hline LEV & 400 & 0,04 & 0,96 & 0,45 & 0,21 \\
\hline LNSIZE & 400 & 21,03 & 33,32 & 27,83 & 1,99 \\
\hline TOBINQ & 400 & 0,20 & 3,47 & 1,28 & 0,76 \\
\hline
\end{tabular}

Table 1 explains that the firm value measured by Tobin Q from manufacturing firm on the Indonesian capital market has an average of 1,28. Tobin $\mathrm{Q}$ ratio shows a value above one, which shows that most of the sample companies have a higher market value when compared to company assets. The description of the profitability data of manufacturing firm in the Indonesian capital market shows a figure of 0,04 . The average profitability of a sample company is small. The sample companies have quite varied profitability conditions where there are companies that have a ROA of 0,36 , but there are also those that have a ROA of - 0,20 . A negative ROA ratio indicates that the company is experiencing losses.

In the audit quality variable, we can know that the audit quality has an average of 0,32 . The data shows that only $32 \%$ of manufacturing firm on the Indonesian capital market use the services of a big 4. public accounting firm. The value can be said to be low because it means that it is still under $50 \%$ of sample companies that use the services of a big auditor 4 . The phenomenon is quite interesting for researchers, although a little outside the context of this research, it can be the basis for further research on audit quality in Indonesian. 
This study uses leverage and company size as control variables. In clarifying the leverage data, we can see that the average manufacturing company in the Indonesian capital market has average leverage of 0,45 . Even though there are sample companies that have a debt ratio of up to $97 \%$, the average manufacturing company in Indonesian has a fairly secure debt ratio. In the description of firm size data, we know that manufacturing firm in the Indonesian capital market have an average firm size of 27,83 , the smallest value of the firm size of 21,03 while the largest value of the firm size of 33,32. Table 2 below will provide an overview of the correlations between research variables.

Table 2. Correlation Analysis

\begin{tabular}{|c|c|c|c|c|c|}
\hline & ROA & DUMBIG4 & LEV & LNSIZE TOBINQ \\
\hline ROA & 1 & & & & \\
\hline DUMBIG4 & $0,260^{* *}$ & 1 & & & \\
\hline LEV & $-0,458^{* *}$ & $-0,100^{*}$ & 1 & & \\
\hline LNSIZE & $0,149^{* *}$ & $0,419^{* *}$ & 0,016 & 1 & \\
\hline TOBINQ & $0,362^{* *}$ & $0,257^{* *}$ & $-0,021$ & $0,228^{* *}$ & 1 \\
\hline
\end{tabular}

Based on table 2, we can know that the relationship between leverage and profitability has the biggest correlation with $-0,458$. In contrast, the relationship between company size and leverage has the smallest correlation with a value of 0,016 . The researcher informed that all data used in this study had passed all the classic assumption test components as a prerequisite for multiple regression tests.

\subsection{Result of Hypothesis Testing}

This research examines two research hypotheses. The first hypothesis was tested with multiple regression, which is presented in equation 1 . The second hypothesis is tested by moderated regression analysis, which is presented in the second regression equation.
The following table shows the results of testing the hypothesis test of this study.

Table 3. Regression Test Results

\begin{tabular}{|c|c|c|c|c|}
\hline \multirow{2}{*}{ Variable } & \multicolumn{2}{|c|}{ Equation 1} & \multicolumn{2}{|c|}{ Equation 2} \\
\hline & Coef. & $p$-value & Coef. & p-value \\
\hline Constant & $-0,434$ & 0,404 & $-0,445$ & 0,390 \\
\hline $\mathrm{ROA}$ & 3,869 & 0,000 & 2,801 & 0,000 \\
\hline DUMBIG4 & 0,200 & 0,015 & 0,099 & 0,294 \\
\hline LNSIZE & 0,044 & 0,021 & 0,046 & 0,015 \\
\hline LEV & 0,611 & 0,001 & 0,567 & 0,003 \\
\hline ROA*DUMBIG4 & - & - & 2,068 & 0,027 \\
\hline Number of Observations & 400 & & 400 & \\
\hline Adjusted $\mathrm{R}^{2}$ & 0,187 & & 0,195 & \\
\hline$\Delta$ Adjusted $\mathrm{R}^{2}$ & - & & 0,008 & \\
\hline F-Statistic & 23,963 & & 20,436 & \\
\hline Prob (F-Statistic) & 0,000 & & 0,000 & \\
\hline
\end{tabular}

Table 3 shows the results of the hypothesis test for the first regression of the equation and the second equation of the regression. Regression equation 1 shows the coefficient of determination (adjusted $\mathrm{R}$ square) of 0,187 . The results of this test indicate that $18,7 \%$ of variations in firm value change are influenced by company profitability, audit quality, leverage and firm size. There is an $81,3 \%$ change in firm value that is influenced by other factors outside the first equation model. The next process is to test the regression $\mathrm{F}$ value. The results of the $\mathrm{F}$ value test showed an $F$ value of 23,963 with a p-value of 0,000 . Based on these results, we can conclude that the first regression model is already fit between the model and the data used.

The second regression equation shows the coefficient of determination (adjusted $\mathrm{R}$ square) of 0,195. The second regression equation shows that 19,5\% 
change in firm value is influenced by the variable profitability of the company, audit quality, interaction between profitability and audit quality, corporate leverage and firm size. There is $80,5 \%$ change in firm value that is influenced by other factors outside the second equation regression model. In this second equation regression, there is an increase in the coefficient of determination of $0,8 \%$ when compared to the first regression equation. Although the increase in the coefficient of determination is not too large, the inclusion of moderation variables in the research model has been able to improve the research model. The next stage is to test the regression $\mathrm{F}$ value for the second regression equation. F value test results show a regression $F$ value of 20,436 with a p-value of 0,000. Based on this, we can conclude that the second regression model is fit between the model and the data used.

Table 3 shows the results of hypothesis 1 research. Hypothesis 1 in this study aims to prove the effect of profitability on firm value in the case of a manufacturing firm on the Indonesian capital market. Based on table 3 of the first regression equation, we can see that the ROA variable has a regression coefficient of 3,869 with a p-value of 0,000 . Regression testing for ROA variables gives significant results so that researchers can conclude that profitability has a positive effect on firm value in a manufacturing firm on the Indonesian capital market. Hypothesis 1 of this study is supported. The results of this study support the results of Purwohandoko's research (2017), Tamrin et al. (2017), and Kontesa (2015), which have found a positive effect of profitability on firm value.

Table 3 on the side of the second regression equation shows the regression results with moderating variables. Hypothesis 2 of the study aims to examine the moderating role of audit quality on the effect of profitability on firm value for the case of manufacturing firm on the Indonesian capital market. Based on table 3 of the second regression equation, we can see that the interaction variable between profitability and audit quality (notated by ROA * DUMBIG4) has a regression coefficient of 2,068 with a p-value of 0,027. Moderated regression analysis test gives significant results so that researchers can conclude that audit quality moderates the effect of profitability on firm value in the case of manufacturing firm on the Indonesian capital market. Hypothesis 2 of this study is supported. The regression coefficient of the interaction variable between profitability and audit quality shows a positive value, which means that audit quality reinforces the effect of profitability on the firm value of manufacturing firm on the Indonesian capital market. This study's results complement and strengthen previous research on profitability, audit quality, and firm value. Previous research has found the effect of profitability on firm value and the influence of audit quality on firm value. However, this study can provide relatively recent evidence of the effect of moderation on audit quality on the effect of profitability on the value of manufacturing firm on the Indonesian capital market.

The results of the testing of the control variables show that firm size has a positive effect on firm value in both the first equation regression and the second equation regression. This study's results support the research results of Dang et al. (2019), who found a positive effect on the firm size on firm value. Companies with large firm sizes are considered to have lower business risks when compared to small companies. Testing of leverage control variables also shows significant results where leverage has a positive effect on firm value in both the first equation regression and the second equation regression. The results of this study do not support the research results of Dang et al. (2019) which found a negative effect on the ratio of debt to 
firm value but supported part of the research results of Wang and Huang (2014) who found a positive effect of leverage on firm value.

\subsection{Discussion}

This study found an effect of profitability on firm value in the case of manufacturing firm on the Indonesian capital market. The results of this study support the results of previous studies such as Ghosh et al. (2005) who discovered the effect of growing earnings on earnings response coefficient, and Mian and Sankaraguruswamy (2012) who discovered the sensitivity of earnings information to changes in stock prices in the capital market. Shivakumar and Urcan (2017) explain that a company's ability to obtain earnings can be sent as a signal of future profitability. Investors evaluate the signal as a possible increase in welfare in the future. If an increase in corporate profits can be quickly and precisely converted into cash, an increase in profit can be interpreted as sufficient internal cash availability. Increased availability of internal cash can help companies in the event of financial distress and increase corporate business investment. It can be distributed to company owners in the form of dividends. The results of this study also support Dang et al. (2019) opinion, which explains that the higher the business profitability, the better its stock price. The increase in profits will impact the increasing number of investors who want to buy shares of the company so that the company's stock price increases. The increase in stock prices is a potential profit for capital market investors to get capital gains.

This study found evidence that audit quality reinforces the effect of profitability on firm value in manufacturing firm on the Indonesian capital market. Beyer et al. (2019) explained that earnings management and corporate earnings quality is a sensitive issue associ- ated with agency relationships and business decisions of financial statement users. If the quality of earnings is low, uncertainty will emerge from the manager's side of the company's profits, while also increasing information asymmetry between managers and investors. Audit quality is thought to be information that influences investors' business considerations. If the company submits earnings information in its financial statements, while the financial statements are audited by qualified auditors (the big four), investors become more trustworthy. Investors assess earnings information obtained through quality audits, low earnings management, and describe real business conditions.

Investor's reaction to earnings information is inseparable from the competitive advantage of big four auditors compared to non-big four auditors. Francis and $\mathrm{Yu}$ (2009) state that big four auditors have collective experience in administering audits on public companies. Big four auditors have more hours of audit experience to better detect material misstatements in audited public companies. Big four auditors are considered to have better human capital and more experienced audit personnel, so they have a higher chance of detecting material misstatements in the financial statements. Eshleman and Guo (2014) state that when accepting clients, the big four auditors will try to minimize the risk borne by the client by providing higher quality audited financial statements. Investors and creditors have more confidence in companies that use a big four auditor's services because they are considered to have helped investors and creditors assess the quality of the company's financial statements.

\section{Conclusion}

This study examines the effect of profitability on firm value with audit quality as a moderating variable in 
the case of manufacturing firm on the Indonesian capital market in 2013-2107. This study found that profitability affects firm value, while audit quality is a moderating variable that reinforces the effect of profitability on firm value. This research shows that investors have a greater appreciation for the reporting of earnings of manufacturing firm on the Indonesian capital market, which was audited by big four auditors.

The managerial implication of this research is that company managers at the Indonesian capital market can use big four public accountants as an effort to increase investor confidence in corporate financial reporting, attract investors to invest, and as an effort to increase firm value.

This study's limitation is that this research model only tests earnings information in the form of a company's profitability ratio. Future studies are suggested to re-analyze this research model by examining the role of earnings quality associated with audit quality and firm value. Future studies are expected to evaluate not only earnings information but also analyze market responses to earnings quality and audit quality of the company.

\section{References}

Afza, T., \& Nazir., M. S. (2014). Audit Quality and Firm Value: A Case of Pakistan. Research Journal of Applied Sciences, Engineering and Technology, 7(9), 1803-1810. https://doi.org/10.19026/rjaset.7.465

AlNajjar, F. K., \& Belkaoui, A. R. (1999). Multinationality, Profitability and Firm Value. Managerial Finance, 25(12), 31-41. https://doi. org/10.1108/03074359910766325

Alsmairat, Y. Y. Y., Yusoff, W. S., Fairuz, M., Saleh, M., \& Norida. B. (2018). International Diversification, Audit Quality and Firm Value of Jordanian Public
Listed Firm. Academy of Accounting and Financial Studies Journal, 22(Special Issue), 1-7.

Aobdia, D., Lin, C. J., \& Petacchi, R. (2015). Capital Market Consequences of Audit Partner Quality. The Accounting Review, 90(6), 2143-2176. https://doi. org/10.2308/accr-51054

Ball, R., \& Brown, P. (1968). An Empirical Evaluation of Accounting Income Numbers. Journal of Accounting Research, 6, 159-178. https://doi. org/10.2307/2490232

Ball, R., Kothari, S. P., \& Watts, R. L. (1993). Economic Determinants of the Relation between Earnings Changes and Stock Returns. The Accounting Review, 68(3), 622-638.

Balsam, S., Krishnan, J., \& Yang, J. S. (2003). Auditor Industry Specialization and Earnings Quality. Auditing: A Journal of Practice \& Theory, 22(2), 71-97. https://doi.org/10.2308/aud.2003.22.2.71

Barth, M. E., \& Landsman, W. R. (2018). Using Fair Value Earnings to Assess Firm Value. Accounting Horizons, 32(4), 49-58. https://doi.org/10.2308/acch-52156

Beaver, W. H. (1968). The Information Content of Annual Earnings Announcements. Journal of Accounting Research Supplement, 6(3), 67-92. https://doi. org/10.2307/2490070

Beyer, A., Guttman. I., \& Marinovic, I., (2019). Earnings Management and Earnings Quality: Theory and Evidence. The Accounting Review, 94(4), 77-101. https:// doi.org/10.2308/accr-52282

Brooks, R. M. (1994). Bid-Ask Spread Components around Anticipated Announcements. Journal of Financial Research, 17(3), 375-386. https://doi. org/10.1111/j.1475-6803.1994.tb00199.x

Cano Rodríguez, M., \& Sánchez Alegría, S. (2012). The Value of Audit Quality in Public and Private Companies: Evidence from Spain. Journal of Management \& Governance, 16, 683-706. https://doi.org/10.1007/ s10997-011-9183-4 
Chan, H., Faff, R., \& Ramsay, A. (2005). Firm Size and the Information Content of Annual Earnings Announcements: Australian Evidence. Journal of Business Finance \& Accounting, 32(1), 221-253. https://doi. org/10.1111/j.0306-686X.2005.00593.x

Chen, J. Z., Chen, M. H, Chin, C. L., \& Lobo, G. J. (2020). Do Firms That Have a Common Signing Auditor Exhibit Higher Earnings Comparability? The Accounting Review, 95(3), 115-143. https://doi. org/10.2308/accr-52522

Chen, L. J., \& Chen, S. Y. (2011). The Influence of Profitability on Firm Value with Capital Structure as The Mediator and Firm Size and Industry as Moderators. Investment Management and Financial Innovations, 8(3), 121-129.

Chen, L. H., Folsom, D. M., Paek, W., \& Sami, H. (2014). Accounting Conservatism, Earnings Persistence, and Pricing Multiples on Earnings. Accounting Horizons, 28(2), 233-260. https://doi.org/10.2308/acch-50664

Dang, H. N., Vu, V. T. T., Ngo, X. T., \& Hoang, H. T. V. (2019). Study the Impact of Growth, Firm Size, Capital Structure, and Profitability on Enterprise Value: Evidence of Enterprises in Vietnam. The Journal of Corporate Accounting of Finance, 30(1), 146-162. https://doi.org/10.1002/jcaf.22371

DeAngelo, L. (1981). Auditor Size and Audit Quality. Journal of Accounting and Economics, 3(3), 183-199. https://doi.org/10.1016/0165-4101(81)90002-1

Dennis, S. A., Griffin, J. B., \& Zehms, K. M. (2019). The Value Relevance of Managers' and Auditors' Disclosures about Material Measurement Uncertainty. The Accounting Review, 94(4), 215-243. https://doi. org/10.2308/accr-52272

Dimitropoulos, P. E., \& Asteriou, D. (2009). The Relationship between Earnings and Stock Returns: Empirical Evidence from the Greek Capital Market. International Journal of Economics and Finance, 1(1), 40-50. https://doi.org/10.5539/ijef.v1n1p40
Doyle, J. T., Ge, W., \& McVay, S. (2007). Accruals Quality and Internal Control over Financial Reporting. The Accounting Review, 82(5), 1141-1170. https://doi. org/10.2308/accr.2007.82.5.1141

Elliott, W. B., Fanning, K., \& Peecher, M. E. (2020). Do Investors Value Higher Financial Reporting Quality, and Can Expanded Audit Reports Unlock This Value? The Accounting Review, 95(2), 141-165. https://doi. org/10.2308/accr-52508

Easton, P. D., \& Harris, T. S. (1991). Earnings as Explanatory Variable for Returns. Journal of Accounting Research, 29(1), 19-36. https://doi.org/10.2307/2491026

Eshleman, J. D., \& Guo, P. (2014). Do Big 4 Auditors Provide Higher Audit Quality after Controlling for the Endogenous Choice of Auditor? Auditing: A Journal of Practice \& Theory, 22(4), 197-219. https://doi. org/10.2308/ajpt-50792

Fairfield, P. M., Whisenant, J. S., \& Yohn, T. L. (2003). Accrued Earnings and Growth: Implications for Future Profitability and Market Mispricing. The Accounting Review, 78 (1), 353-371. https://doi. org/10.2308/accr.2003.78.1.353

Fooladi, M., \& Farhadi, M. (2011). Corporate Governance and Audit Process. International Conference on Humanities, Society and Culture, 2, 306-311.

Francis, J. R., \& Wang, D. (2008). The Joint Effect of Investor Protection and Big 4 Audits on Earnings Quality around the World. Contemporary Accounting Research, 25(1), 157-191. https://doi.org/10.1506/car.25.1.6

Francis, J. R., \& Yu., M. D. (2009). Big 4 Office Size and Audit Quality. The Accounting Review, 84(5), 15211552. https://doi.org/10.2308/accr.2009.84.5.1521

Ghosh, A., Gu, Z., Jian, P. C. (2005). Sustained Earnings and Revenue Growth, Earnings Quality, and Earnings Response Coefficients. Review of Accounting Studies, 10(1), 33-57. https://doi.org/10.1007/s11142-0046339-3

Contabilidad y Negocios (15) 30, 2020 / ISSN 1992-1896 
Hamdan, A. M. M., Kukrija, G., Awwad, B. S. A., \& Dergham, M. M. (2012). The Auditing Quality and Accounting Conservatism. International Management Review, 8(2), 33-50.

Hurley, P. J, \& Mayhew, B. W. (2019). Market Reactions to a High-Quality Auditor and Managerial Preference for Audit Quality. Auditing: A Journal of Practice \& Theory, 38(4), 131-149. https://doi.org/10.2308/ajpt52478

Hussainey, K. (2009). The Impact of AuditQuality on Earnings Predictability. Managerial Auditing Journal, 24(4), 340351. https://doi.org/10.1108/02686900910948189

Jensen, M. C., \& Meckling, W. H. (1976). Theory of The Firm: Managerial Behavior, Agency Cost and Ownership Structure. Journal of Financial Economics, 3(4), 305360. https://doi.org/10.1016/0304-405X(76)90026-X

Jiang, J. X., Wang, I. Y., \& Wang, K. P. (2019). Big N Auditors and Audit Quality: New Evidence from Quasi-Experiments. The Accounting Review, 94(1), 205-227. https://doi.org/10.2308/accr-52106

Kazemi, H., Hemmati, H., \& Faridvand, R. (2011). Investigating the Relationship Between Conservatism Accounting and Earnings Attributes. World Applied Sciences Journal, 12(9), 1385-1396.

Kerr, J. N., \& Ozel, N. B. (2015). Earnings Announcements, Information Asymmetry, and Timing of Debt Offerings. The Accounting Review, 90(6), 2375-2410. https://doi.org/10.2308/accr-51116

Kieso, D. E., Weygandt, J. J., \& Warfield, T. D. (2011). Intermediate Accounting. 14th edition. Hoboken, New Jersey: John Wiley \& Sons.

Kontesa, M. (2015). Capital Structure, Profitability, and Firm Value. Whats New?. Research Journal of Finance and Accounting, 6(20), 185-192.

Kronenberger, S., \& Plietzsch, E. (2017). The Auditor's Reputation and Its Effect on Audit Quality and Audit Premia. Discussion Paper Series in Economics and Management, 17(11), 1-50.
LaFond, R., \& Watts, R. L. (2008). The Information Role of Conservatism. The Accounting Review, 83(2), 447478. https://doi.org/10.2308/accr.2008.83.2.447

Lev, B. (1989). On the Usefulness of Earnings and Earnings Research: Lessons and directions from Two Decade of Empirical Research. Journal of Accounting Research, 27, 153-191. https://doi.org/10.2307/2491070

Li, J., \& Lin, J. W. (2005). The Relation Between Earnings Management and Audit Quality. Journal of Accounting and Finance Research, 13(1), 1-11.

Lin, J. W., \& Hwang, M. I. (2010). Audit Quality, Corporate Governance, and Earnings Management: A Meta-Analysis. International Journal of Auditing, 15, 57-77. https:// doi.org/10.1111/j.1099-1123.2009.00403.x

Liow, K. H. (2010). Firm Value, Growth, Profitability and Capital Structure of Listed Real Estate Companies: An International Perspective. Journal of Property Research, 27(2), 119-146. https://doi.org/10.1080/09599916.2 010.500459

Mian, G. M., \& Sankaraguruswamy, S. (2012). Investor Sentiment and Stock Market Response to Earnings News. The Accounting Review, 87(4), 1357-1384. https://doi.org/10.2308/accr-50158

Mule, R. K., Mukras, M. S., \& Nzioka, O. M. (2015). Corporate Size, Profitability and Market Value: An Econometric Panel Analysis of Listed Firms in Kenya. European Scientific Journal, 11(13), 376-296.

Ofer, A. R. (1975). Investor Expectations of Earnings Growth, Their Accuracy and Effects on The Structure of Realized Rates of Return. The Journal of Finance, 30(2), 509-523. https://doi.org/10.2307/2978730

Ohlson, J. A., \& Shroff, P. K. (1992). Changes Versus Levels in Earnings as Explanatory Variables for Returns: Some Theoretical Considerations. Journal of Accounting Research, 39(2), 201-226.

Orpurt, S. F., \& Zang, Y. (2009). Do Direct Cash Flow Disclosures Help Predict Future Operating Cash Flows 
and Earnings? The Accounting Review, 84(3), 893935. https://doi.org/10.2308/accr.2009.84.3.893

Pfeiffer, G. M., \& Shields, T. W. (2015). Performance-Based Compensation and Firm Value-Experimental Evidence. Accounting Horizons, 29(4), 777-798. https:/doi. org/10.2308/acch-51143

Purwohandoko (2017). The Influence of Firm's Size, Growth, and Profitability on Firm Value with Capital Structure as The Mediator: A Study on The Agricultural Firms Listed in the Indonesian Stock Exchange. International Journal of Economics and Finance, 9(8), 103-110. https://doi.org/10.5539/ijef.v9n8p103

Reyad, S. M. R. (2012). Accounting Conservatism and Auditing Quality: An Applied Study on Egyptian Corporations. European Journal of Business and Management, 4(21), 108-116.

Reyad, S. M. R. (2013). The Role of Auditing Quality as A Tool of Corporate Governance in Enhancing Earnings Quality: Evidence from Egypt. International Management Review, 9(2), 83-93. https://doi. org/10.5937/EkoIzavov1711029I

Saji, T.G., \& Harikumar, S. (2015). Earnings Growth and Value Premium: The Indian Experience. The Journal for Decision Makers, 40(4), 444-454. https://doi. org/10.1177/0256090915608542

Senteney, D. L. (1991). Characteristics of Earnings News and Operational Efficiency in the NASDAQ Securities Market. Review of Financial Economics, 1(1), 49-61. https://doi.org/10.1002/j.1873-5924.1991. tb00541.x
Shivakumar, L., \& Urcan, O. (2017). Why Does Aggregate Earnings Growth Reflect Information about Future Inflation? The Accounting Review, 92(6), 247276. https://doi.org/10.2308/accr-51714

Skinner, D. J., \& Srinivasan, S. (2012). Audit Quality and Auditor Reputation: Evidence from Japan. The Accounting Review, 87(5), 1737-1765. https://doi. org/10.2308/accr-50198

Sucuahi, W., \& Cambarihan, J. M. (2016). Influence of Profitability to the Firm Value of Diversified Companies in the Philippines. Accounting and Finance Research, 5(2), 149-153. https://doi.org/10.5430/afr. $\mathrm{v} 5 \mathrm{n} 2 \mathrm{p} 149$

Tamrin, H. M., Mus, R., Sudirman., \& Arfah, A. (2017). Effect of profitability and Dividend Policy on Corporate Governance and Firm Value: Evidence from The Indonesian Manufacturing Sectors. IOSR Journal of Business and Management, 19(10), 66-74. https://doi. org/10.31237/osf.io/sfjqc

Verdi, R. S. (2006). Financial Reporting Quality and Investment Efficiency. SSRN Electronic Journal. https:// doi.org/10.2139/ssrn.930922

Wang, Y., \& Huang, Y. (2014). How Do Auditors Increase Substantially Firm Value? International Journal of Economics and Finance, 6(10), 76-82. https://doi. org/10.5539/ijef.v6n10p76

Fecha de recepción: 15 de julio de 2020 Fecha de aceptación: 18 de octubre de 2020 Correspondencia: gonggeng14@gmail.com 